\title{
Decision Support System for Determining Critical Land in Klaten Regency
}

\author{
Yudi Eko Windarto ${ }^{1 *}$, Nurhadi Bashit ${ }^{2}$, Novia Sari Ristianti ${ }^{3}$, Desyta Ulfiana ${ }^{4}$, Devina \\ Trisnawati ${ }^{5}$ \\ ${ }^{1}$ Department of Computer Engineering, Faculty of Engineering, Diponegoro University, Indonesia \\ ${ }^{2}$ Department of Geodetic Engineering, Faculty of Engineering, Diponegoro University, Indonesia \\ ${ }^{3}$ Department of Urban and Regional Planning Engineering, Faculty of Engineering, Diponegoro \\ University, Indonesia \\ ${ }^{4}$ Department of Civil Engineering, Faculty of Engineering, Diponegoro University, Indonesia \\ ${ }^{5}$ Department of Geological Engineering, Faculty of Engineering, Diponegoro University, Indonesia
}

\begin{abstract}
Critical land has become a problem in the world. Critical land is very detrimental to the health of the land. Several factors cause the land to become critical. One of them is the use of land that is not by the capabilities of the land. If no repairs made, the land will be physically, chemically, and biologically damaged. Klaten Regency is one of the regencies in Central Java Province, which has quite extensive critical land. It is necessary to monitor and improve land quality regularly to avoid critical land problems. Data and information on critical land obtained from Klaten Regency processed into a decision support system. Decision Support System uses a combination of Analytical Hierarchy Process (AHP) and Technique For Order Preference by Similarity to Ideal Solution (TOPSIS) methods. In this research, a Web-based Decision Support System created to determine the critical land area in Klaten Regency. The information system created has an alternative menu and criteria that determine the potential of critical land in Klaten Regency, making it easier for users to obtain information.
\end{abstract}

Keywords. Critical Land, Data, Information, and Decision Support System

\section{Introduction}

Critical land becomes a problem in data processing in the environmental field[1, 2]. Regional Development Planning Agency Klaten Regency has difficulty in determining critical land. This is due to various parameter values and criteria. So we need a system that can provide information about critical land in Klaten Regency accurately, effectively and

* Corresponding author: yudi@live.undip.ac.id 
efficiently. Therefore, the system created can assist the Regional Development Planning Agency Klaten Regency in making decisions to determine the potential for critical land in accordance with existing criteria. This study uses 6 criteria in determining Critical Land. These criteria include slope, land use, geology, rainfall, hidrogeology and soil types. Alternatively there are 26 subdistricts including Pedan, Karangdowo, Karanganom, Jatinom, Ngawen, Juwiring, Manisrenggo, Kalikotes, Ceper, Trucuk, Prambanan, Jogonalan, Bayat, Cawas, Delanggu, Kemalang, Tulung, Polanharjo, Wonosari, Karangnongko, Gantiwarno, Klaten Utara, Klaten Tengah, Klaten Selatan, Kebonarum, Wedi. The implementation of Analytic Hierarchy Process (AHP) and Technique For Order Preference by Similarity to Ideal Solution (TOPSIS) methods as a Decision Support System will provide more effective and efficient processing of this data and can be used as a mapping illustration in an area to determine critical land.

\section{Literature Review}

Utilizing AHP method was previously used to rank options according to the relevance of the criteria weights for delineation of groundwater potential zones[3]. AHP method is a decision making method to calculate priority criteria that meet the requirements of several alternatives based on the judgment of the decision maker[4, 5]. Although the AHP method has several advantages, it cannot be separated from the shortcomings, the method is less effective if it is used in cases that have a large number of criteria and alternatives. Other methods are needed to be combined in order to obtain more effective results [6-8]. AHP when used to rank requires a relatively longer time and only compares between criteria, there is no normalization process and calculation of its costs and benefits $[9,10,12]$. The AHP method is also used to choosing the optimal technology to rehabilitate the pipes in water distribution systems[13]. TOPSIS is a multi-criteria method used to identify solutions from alternative sets based on simultaneous minimization of ideal point distances and maximizing distances from low points [14-17].

\section{Research Methodology}

In this study using the Analytic Hierarchy Process (AHP) method, will be calculated from the criteria weight value to obtain a total priority value (tpv), which will then be used in calculations with the Technique For Order Preference by Similarity to Ideal Solution (TOPSIS) method.

\subsection{Criteria Weights}

First we need criteria data which contains the weights which in this case are 6 influential criteria obtained from the Klaten Regency field. These data are shown in the table 1. 
Table 1. Parameters and values data

\begin{tabular}{|c|c|c|}
\hline Criteria & Value & Explanation \\
\hline Slope & 5 & Benefit \\
\hline Land Use & 7 & Benefit \\
\hline Geology & 3 & Benefit \\
\hline Rainfall & 5 & Cost \\
\hline Hidrogeology & 7 & Benefit \\
\hline Soil Types & 7 & Cost \\
\hline
\end{tabular}

From the data above will be made one by one comparison for each criterion so that the data obtained as shown in table 2.

Table 2. Parameters and values data

\begin{tabular}{|c|c|c|c|c|c|c|}
\hline Criteria & C1 & C2 & C3 & C4 & C5 & C6 \\
\hline C1 & 1 & 1.4 & 0.6 & 1 & 1.4 & 1.4 \\
\hline C2 & 0,71 & 1 & 0,43 & 0,71 & 1 & 1 \\
\hline C3 & 1,67 & 2,33 & 1 & 1,67 & 2,33 & 2,33 \\
\hline C4 & 1 & 1.4 & 0.6 & 1 & 1.4 & 1.4 \\
\hline C5 & 0,71 & 1 & 0,43 & 0,71 & 1 & 1 \\
\hline C6 & 0,72 & 1 & 0,43 & 0,71 & 1 & 1 \\
\hline Jumlah & 5,81 & 8,13 & 3,49 & 5,81 & 8,13 & 8,13 \\
\hline
\end{tabular}

Explanation:
- C1: Slope
- C2: Land Use
- $\quad$ C3: Geology
- C4: Rainfall
- C5: Hydrogeology
- C6: Soil Types

\subsection{Normalization of Criteria Weights}

The next stage is the weighted criteria that have been compared normalized by dividing by the number of values in one row. Following is the acquisition of normalization values shown in table 3 .

Table 3. Parameter Weight Table

\begin{tabular}{|c|c|c|c|c|c|c|c|}
\hline Criteria & C1 & C2 & C3 & C4 & C5 & C6 & Total \\
\hline C1 & 0.1721 & 0.1721 & 0.1721 & 0.1721 & 0.1721 & 0.1721 & 1,0328 \\
\hline C2 & 0.123 & 0.123 & 0.123 & 0.123 & 0.123 & 0.123 & 0,7377 \\
\hline C3 & 0.2869 & 0.2869 & 0.2869 & 0.2869 & 0.2869 & 0.2869 & 1,7213 \\
\hline C4 & 0.1721 & 0.1721 & 0.1721 & 0.1721 & 0.1721 & 0.1721 & 1,0328 \\
\hline C5 & 0.1230 & 0.1230 & 0.1230 & 0.1230 & 0.1230 & 0.1230 & 0,7377 \\
\hline C6 & 0.1230 & 0.123 & 0.123 & 0.123 & 0.123 & 0.123 & 0,7377 \\
\hline
\end{tabular}




\subsection{Determination of Priority Weight Value Criteria}

At this stage the processing has been carried out using the formula weight criteria or total priority value, namely:

$$
T P V=\frac{\sum w_{i j}}{n}
$$

Explanation:

- TPV : Priority weights criteria value

- $\quad \sum w_{\text {i⿱ }} \quad$ : Total normalization sum of weights criteria

- $\mathrm{n} \quad$ : Number of criteria

Samples of processing the criteria weights from the slope parameters can be obtained with the formula for priority weights criteria, namely:

$$
T P V=\frac{1.0328}{6}=0,1721
$$

Likewise with other criteria will be done the same way with the formula of the priority value of criteria weights. The results of data processing the priority value of criteria weights can be shown in table 4 .

Table 4. Table of Relative Weights

\begin{tabular}{|c|c|}
\hline Parameter & $\begin{array}{l}\text { Relative } \\
\text { Weights }\end{array}$ \\
\hline Slope (C1) & 0.1721 \\
\hline Land Use (C2) & 0.123 \\
\hline Geology (C3) & 0.2868 \\
\hline Rainfall (C4) & 0.1721 \\
\hline Hidrogeology (C5) & 0.123 \\
\hline Soil Types (C6) & 0.123 \\
\hline
\end{tabular}

In the Topsis method, a calculation that takes the tpv value from the results of the previous method is AHP to obtain the final value from each of its districts.

\subsection{Determination of Parameters and Values}

First, the required criteria or parameter data and alternative data and their values are determined from the field, namely the Geodetic Department, in this case in the form of subdistrict data in Klaten Regency. These data are shown in table 5.

Table 5. Parameter and Values

\begin{tabular}{|c|c|c|c|c|c|c|}
\hline \multirow{2}{*}{ Area } & \multicolumn{7}{|c|}{ Criteria } \\
\cline { 2 - 8 } & $\mathrm{C} 1$ & $\mathrm{C} 2$ & $\mathrm{C} 3$ & $\mathrm{C} 4$ & $\mathrm{C} 5$ & C6 \\
\hline Pedan & 0 & 1 & 0 & 1 & 1 & 0 \\
\hline Karangdowo & 0 & 1 & 4 & 1 & 1 & 0 \\
\hline Karanganom & 0 & 1 & 0 & 0 & 0 & 0 \\
\hline Jatinom & 1 & 1 & 0 & 0 & 0 & 0 \\
\hline Ngawen & 0 & 1 & 0 & 0 & 0 & 0 \\
\hline
\end{tabular}




\begin{tabular}{|c|c|c|c|c|c|c|}
\hline Juwiring & 0 & 1 & 2 & 2 & 1 & 0 \\
\hline Manisrenggo & 1 & 1 & 0 & 1 & 0 & 1 \\
\hline Kalikotes & 0 & 1 & 3 & 1 & 0 & 0 \\
\hline Ceper & 0 & 1 & 0 & 1 & 0 & 0 \\
\hline Trucuk & 1 & 3 & 0 & 1 & 0 & 0 \\
\hline Prambanan & 1 & 3 & 0 & 1 & 0 & 1 \\
\hline Jogonalan & 0 & 1 & 0 & 1 & 0 & 1 \\
\hline Bayat & 2 & 3 & 1 & 1 & 2 & 1 \\
\hline Cawas & 1 & 1 & 0 & 1 & 2 & 1 \\
\hline Delanggu & 0 & 1 & 0 & 2 & 0 & 0 \\
\hline Kemalang & 2 & 0 & 0 & 1 & 1 & 1 \\
\hline Tulung & 1 & 1 & 0 & 0 & 0 & 0 \\
\hline Polanharjo & 0 & 1 & 0 & 2 & 0 & 0 \\
\hline Wonosari & 0 & 1 & 2 & 2 & 0 & 0 \\
\hline Karangnongko & 1 & 1 & 0 & 1 & 0 & 0 \\
\hline Gantiwarno & 1 & 1 & 2 & 1 & 2 & 1 \\
\hline Klaten Utara & 0 & 3 & 0 & 0 & 0 & 0 \\
\hline Klaten Tengah & 0 & 3 & 3 & 0 & 0 & 0 \\
\hline Klaten Selatan & 0 & 4 & 0 & 0 & 0 & 0 \\
\hline Kebonarum & 0 & 1 & 0 & 1 & 0 & 0 \\
\hline Wedi & 2 & 1 & 0 & 1 & 2 & 1 \\
\hline
\end{tabular}

Explanation :

- C1: Slope

- C2: Land Use

- C3: Geology

- C4: Rainfall

- C5: Hydrogeology

- C6: Soil Types

\subsection{Determination The Value Divisor}

The next step is to determine the value of the divisor by using the following formula:

$$
y=\sqrt{\sum_{j=1}^{m} x_{i j}^{2}}
$$

Explanation :

- y : Divider Value

- $x_{\text {if }} \quad:$ i-alternative performance rating for the $\mathrm{j}$-criterion

Samples determining the value of the divider from the slope parameter can be obtained by the formula of the divider value :

$$
\begin{aligned}
y & =\sqrt{0^{2}+0^{2}+0^{2}+1^{2}+0^{2}+0^{2}+1^{2}+0^{2}+0^{2}+1^{2}+1^{2}+0^{2}+2^{2}} \\
& =4.4721
\end{aligned}
$$


Likewise with other criteria will be done in the same way with the divisor value formula. The results of processing the divider value data can be shown in table 6 .

Table 6. Divider Value Table

\begin{tabular}{|c|c|}
\hline Parameter & Relative Weight \\
\hline Slope (C1) & 4.4721 \\
\hline Land Use (C2) & 8.9442 \\
\hline Geology (C3) & 6.8556 \\
\hline Rainfall (C4) & 5.5677 \\
\hline Hidrogeology (C5) & 4.5825 \\
\hline Soil Types (C6) & 2.6457 \\
\hline
\end{tabular}

\subsection{Determination The Normalization Value}

At this stage the processing has been carried out using the normalization formula

$$
r_{i j}=\frac{x_{i j}}{y}
$$

Explanation :

- $r_{\text {弥 }}$ : Normalized Element Value

- $\quad x_{\text {ix }} \quad$ : Alternative performance rating $\mathrm{i}$ to the $\mathrm{j}$ criterion

- y : Divider Value

Normalization processing samples from Pedan Subdistrict slope parameters can be obtained with the normalization formula :

$$
r_{\mathrm{ij}}=\frac{0}{4.4721}=0
$$

Likewise with other parameters and sub-districts carried out with the same normalization formula. Normalization data processing results can be shown in table 7 .

Table 7. Normalization Table

\begin{tabular}{|c|c|c|c|c|c|c|}
\hline \multirow{3}{*}{ Subdistrict } & \multicolumn{7}{|c|}{ Criteria } \\
\cline { 2 - 7 } & $\mathrm{C} 1$ & $\mathrm{C} 2$ & $\mathrm{C} 3$ & $\mathrm{C} 4$ & $\mathrm{C} 5$ & $\mathrm{C} 6$ \\
\hline Pedan & 0 & 0.1118 & 0 & 0.1796 & 0.2182 & 0 \\
\hline Karangdowo & 0 & 0.1118 & 0.5835 & 0.1796 & 0.2182 & 0 \\
\hline Karanganom & 0 & 0.1118 & 0 & 0 & 0 & 0 \\
\hline Jatinom & 0.2236 & 0.1118 & 0 & 0 & 0 & 0 \\
\hline Ngawen & 0 & 0.1118 & 0 & 0 & 0 & 0 \\
\hline Juwiring & 0 & 0.1118 & 0.2917 & 0.3592 & 0.2182 & 0 \\
\hline Manisrenggo & 0.2236 & 0.1118 & 0 & 0.1796 & 0 & 0.3536 \\
\hline Kalikotes & 0 & 0.1118 & 0.4376 & 0.1796 & 0 & 0 \\
\hline Ceper & 0 & 0.1118 & 0 & 0.1796 & 0 & 0 \\
\hline Trucuk & 0.2236 & 0.3354 & 0 & 0.1796 & 0.2182 & 0 \\
\hline Prambanan & 0.2236 & 0.3354 & 0 & 0.1796 & 0 & 0.3536 \\
\hline Jogonalan & 0 & 0.1118 & 0 & 0.1796 & 0 & 0.3536 \\
\hline
\end{tabular}




\begin{tabular}{|c|c|c|c|c|c|c|}
\hline Bayat & 0.4472 & 0.3354 & 0.1459 & 0.1796 & 0.4364 & 0.3536 \\
\hline Cawas & 0.2236 & 0.1118 & 0 & 0.1796 & 0.4364 & 0.3536 \\
\hline Delanggu & 0 & 0.1118 & 0 & 0.3592 & 0 & 0 \\
\hline Kemalang & 0.4472 & 0 & 0 & 0.1796 & 0.2182 & 0.3536 \\
\hline Tulung & 0.2236 & 0.1118 & 0 & 0 & 0 & 0 \\
\hline Polanharjo & 0 & 0.1118 & 0 & 0.3592 & 0 & 0 \\
\hline Wonosari & 0 & 0.1118 & 0.2917 & 0.3592 & 0 & 0 \\
\hline Karangnongko & 0.2236 & 0.1118 & 0 & 0.1796 & 0 & 0 \\
\hline Gantiwarno & 0.2236 & 0.1118 & 0.2917 & 0.1796 & 0.4364 & 0.3536 \\
\hline Klaten Utara & 0 & 0.3354 & 0 & 0 & 0 & 0 \\
\hline Klaten Tengah & 0 & 0.3354 & 0.4376 & 0 & 0 & 0 \\
\hline Klaten Selatan & 0 & 0.4472 & 0 & 0 & 0 & 0 \\
\hline Kebonarum & 0 & 0.1118 & 0 & 0.1796 & 0 & 0 \\
\hline Wedi & 0.4472 & 0.1118 & 0 & 0.1796 & 0.4364 & 0.3536 \\
\hline
\end{tabular}

\subsection{Determination of Weighted Normalization}

At this stage a multiplication is made between the normalized value and the priority value of the criteria weights. Samples of normalization values \& priority values for criteria weights are shown as follows:

Pedan Subdistrict with the slope criteria has a normalization value of 0 based on table 7 . With the priority value of the slope criteria weight is 0.1721 based on table 4 . Then, the weighted normalization value is obtained in the ampelgading area with the slope parameter is 0 . The results of weighted normalization data processing are shown in table 8 .

Table 8. Weighted Normalization Table

\begin{tabular}{|c|c|c|c|c|c|c|}
\hline \multirow{3}{*}{ Subdistrict } & \multicolumn{7}{|c|}{ Criteria } \\
\cline { 2 - 8 } & $\mathrm{C} 1$ & $\mathrm{C} 2$ & $\mathrm{C} 3$ & $\mathrm{C} 4$ & $\mathrm{C} 5$ & $\mathrm{C} 6$ \\
\hline Pedan & 0 & 0.0137 & 0 & 0.0309 & 0.0268 & 0 \\
\hline Karangdowo & 0 & 0.0137 & 0.1674 & 0.0309 & 0.0268 & 0 \\
\hline Karanganom & 0 & 0.0137 & 0 & 0 & 0 & 0 \\
\hline Jatinom & 0.0385 & 0.0137 & 0 & 0 & 0 & 0 \\
\hline Ngawen & 0 & 0.0137 & 0 & 0 & 0 & 0 \\
\hline Juwiring & 0 & 0.0137 & 0.2917 & 0.0618 & 0.0268 & 0 \\
\hline Manisrenggo & 0.0385 & 0.0137 & 0 & 0.0309 & 0 & 0.0435 \\
\hline Kalikotes & 0 & 0.0137 & 0.4376 & 0.0309 & 0 & 0 \\
\hline Ceper & 0 & 0.0137 & 0 & 0.0309 & 0 & 0 \\
\hline Trucuk & 0.0385 & 0.0412 & 0 & 0.0309 & 0.0268 & 0 \\
\hline Prambanan & 0.0385 & 0.0412 & 0 & 0.0309 & 0 & 0.0435 \\
\hline Jogonalan & 0 & 0.0137 & 0 & 0.0309 & 0 & 0.0435 \\
\hline Bayat & 0.077 & 0.0412 & 0.1459 & 0.0309 & 0.0537 & 0.0435 \\
\hline Cawas & 0.0385 & 0.0137 & 0 & 0.0309 & 0.0537 & 0.0435 \\
\hline Delanggu & 0 & 0.0137 & 0 & 0.3592 & 0 & 0 \\
\hline
\end{tabular}




\begin{tabular}{|c|c|c|c|c|c|c|}
\hline Kemalang & 0.077 & 0 & 0 & 0.1796 & 0.0268 & 0.0435 \\
\hline Tulung & 0.0385 & 0.0137 & 0 & 0 & 0 & 0 \\
\hline Polanharjo & 0 & 0.0137 & 0 & 0.0618 & 0 & 0 \\
\hline Wonosari & 0 & 0.0137 & 0.0837 & 0.0618 & 0 & 0 \\
\hline Karangnongko & 0.0385 & 0.0137 & 0 & 0.0309 & 0 & 0 \\
\hline Gantiwarno & 0.0385 & 0.0137 & 0.0837 & 0.0309 & 0.0537 & 0.0435 \\
\hline Klaten Utara & 0 & 0.0412 & 0 & 0 & 0 & 0 \\
\hline Klaten Tengah & 0 & 0.0412 & 0.1255 & 0 & 0 & 0 \\
\hline Klaten Selatan & 0 & 0.055 & 0 & 0 & 0 & 0 \\
\hline Kebonarum & 0 & 0.0137 & 0 & 0.0309 & 0 & 0 \\
\hline Wedi & 0.077 & 0.0137 & 0 & 0.0309 & 0.0537 & 0.0435 \\
\hline
\end{tabular}

\subsection{Determination of The Value of the Ideal Solution}

There are two types of ideal solution values, namely the positive ideal solution $(+)$ and the negative ideal solution (-), performed data processing using the ideal solution formula, namely:

$$
\begin{aligned}
& y_{j}^{+}=\left\{\begin{array}{c}
\max _{i y i j i \text { if } j=b_{e n e f i t}} \\
\min _{\text {iyjijif } j=\text { cost }}
\end{array}\right. \\
& y_{j}^{-}=\left\{\begin{array}{c}
\max _{i y i j i \text { if } j=\text { cost }} \\
\min _{\text {iyijiif } j=\text { benefit }}
\end{array}\right.
\end{aligned}
$$

Explanation:

- $y_{j}^{+}$: Value of Positive Ideal Solution Elements

- $y_{j}^{-}$: Value of Negative Ideal Solution Elements

Sample processing the value of an ideal solution with the criteria for slope which is a benefit by looking at table 8 and table 1 obtained by the evaluation factor formula, namely:

$$
\begin{gathered}
y_{j}^{+}=0,118 \\
y_{j}^{-}=0
\end{gathered}
$$

Likewise with other parameters and sub-districts carried out with the same normalization formula. Normalization data processing results can be shown in table 9 .

Table 9. Weighted Normalization Table

\begin{tabular}{|c|c|c|c|c|c|c|}
\hline $\begin{array}{c}\text { Criteria } \\
\text { Value }\end{array}$ & $\mathrm{C} 1$ & $\mathrm{C} 2$ & $\mathrm{C} 3$ & $\mathrm{C} 4$ & $\mathrm{C} 5$ & $\mathrm{C} 6$ \\
\hline $\mathrm{y}^{+}$ & 0.0769 & 0.0549 & 0.1673 & 0 & 0.0536 & 0 \\
\hline $\mathrm{y}^{-}$ & 0 & 0 & 0 & 0.0618 & 0 & 0.0434 \\
\hline
\end{tabular}




\subsection{Determination of The Value of the Ideal Solution}

At this stage there are two types of alternative value distances, namely the distance of the positive ideal solution value $\left(\mathrm{d}^{+}\right)$and the distance of the negative ideal solution value $\left(\mathrm{d}^{-}\right)$, performed data processing using the alternative value distance formula :

$$
\begin{aligned}
& d_{i}^{+}=\sqrt{\sum_{j=1}^{n}\left(v_{i j}-v_{j}^{+}\right)^{2}} \\
& d_{i}^{-}=\sqrt{\sum_{j=1}^{n}\left(v_{i j}-v_{j}^{-}\right)^{2}}
\end{aligned}
$$

Explanation :

- $\quad v_{j}^{+}$: Value of Positive Ideal Solution Elements

- $v_{j}^{-}$: Value of Negative Ideal Solution Elements

- $d_{i}^{+}$: Positive Alternative Distance Value

- $d_{i}^{-}$: Negative Alternative Distance Value

Likewise with other sub-districts carried out with the same alternative value distance formula. The results of distance data processing of alternative values can be shown in table 10 .

Table 10. Table of Distance Value Alternative Values

\begin{tabular}{|c|c|c|}
\hline Sub-district & $\mathrm{D}^{+}$ & $\mathrm{D}^{-}$ \\
\hline Pedan & 0.19318437015576984 & 0.0612715705063838 \\
\hline Karangdowo & 0.09644744253328615 & 0.17824785287231013 \\
\hline Karanganom & 0.196275266275092 & 0.0768224455477994 \\
\hline Jatinom & 0.18460663675661443 & 0.08592522764319277 \\
\hline Ngawen & 0.196275266275092 & 0.0768224455477994 \\
\hline Juwiring & 0.13847009591311363 & 0.09900984709824051 \\
\hline Manisrenggo & 0.19215879320796622 & 0.05124642780275117 \\
\hline Kalikotes & 0.11494693400276913 & 0.1370931411714353 \\
\hline Ceper & 0.19869513986652404 & 0.05508495960138976 \\
\hline Trucuk & 0.17709923952926668 & 0.08214226909317697 \\
\hline Prambanan & 0.18818424852594512 & 0.06432640807949584 \\
\hline Jogonalan & 0.20339462043995069 & 0.03383400296968558 \\
\hline Bayat & 0.1370931411714353 & 0.11494693400276912 \\
\hline Cawas & 0.1845144750284211 & 0.07419977543544633 \\
\hline Delanggu & 0.2057840955278989 & 0.045591384263558556 \\
\hline Kemalang & 0.18602880577907768 & 0.08718633755130954 \\
\hline Tulung & 0.18460663675661443 & 0.08592522764319277 \\
\hline Polanharjo & 0.2057840955278989 & 0.045591384263558556 \\
\hline Wonosari & 0.14606000546447664 & 0.09530528445151898 \\
\hline Karangnongko & 0.1871774259621279 & 0.06719977217131497 \\
\hline Gantiwarno & 0.11415788504987891 & 0.1118486906494133 \\
\hline Klaten Utara & 0.19238578361586656 & 0.08610097882028894 \\
\hline
\end{tabular}




\begin{tabular}{|c|c|c|}
\hline Klaten Tengah & 0.10365967763576363 & 0.15222862784567232 \\
\hline Klaten Selatan & 0.19189405523819028 & 0.09346714752224805 \\
\hline Kebonarum & 0.19869513986652404 & 0.05508495960138976 \\
\hline Wedi & 0.1804553542830579 & 0.09974956887846859 \\
\hline
\end{tabular}

\subsection{Determination of The Rank}

At this stage it is the final stage of the TOPSIS method by making calculations with the formula:

$$
c_{i}=\frac{d_{i}^{-}}{d_{j}^{-}+d_{i}^{+}}
$$

Explanation :

- $\quad c_{i}$ : End Value

- $\quad d_{i}^{+}$: Positive Alternative Distance Value

- $\quad d_{j}^{-}$: Negative Alternative Distance Value

Samples of ranking processing with alternative Pedan Subdistricts by looking at table 11 obtained with the final result formula, namely:

$$
c_{i}=\frac{0.0612715705063838}{0.0612715705063838+0.19318437015576984}=0.2408
$$

The final results of the Topsis method are shown in table 11.

Table 11. Rank Table

\begin{tabular}{|c|c|c|}
\hline Peringkat & Sub-district & Hasil \\
\hline 1 & Karangdowo & 0.6489 \\
\hline 2 & Klaten Tengah & 0.5949 \\
\hline 3 & Kalikotes & 0.5439 \\
\hline 4 & Gantiwarno & 0.4949 \\
\hline 5 & Bayat & 0.4561 \\
\hline 6 & Juwiring & 0.4169 \\
\hline 7 & Wonosari & 0.3949 \\
\hline 8 & Wedi & 0.356 \\
\hline 9 & Klaten Selatan & 0.3275 \\
\hline 10 & Kemalang & 0.3191 \\
\hline 11 & Jatinom & 0.3176 \\
\hline 12 & Tulung & 0.3176 \\
\hline 13 & Trucuk & 0.3169 \\
\hline 14 & Klaten Utara & 0.3092 \\
\hline 15 & Cawas & 0.2868 \\
\hline 16 & Ngawen & 0.2813 \\
\hline 17 & Karanganom & 0.2813 \\
\hline 18 & Karangnongko & 0.2642 \\
\hline
\end{tabular}




\begin{tabular}{|l|c|l|}
\hline 19 & Prambanan & 0.2547 \\
\hline 20 & Pedan & 0.2408 \\
\hline 21 & Ceper & 0.2171 \\
\hline 22 & Kebonarum & 0.2171 \\
\hline 23 & Manisrenggo & 0.2105 \\
\hline 24 & Delanggu & 0.1814 \\
\hline 25 & Polanharjo & 0.1814 \\
\hline 26 & Jogonalan & 0.1426 \\
\hline
\end{tabular}

A Web-based Decision Support System created to determine the critical land area in Klaten Regency. The information system created has an alternative menu and criteria that determine the potential of critical land in Klaten Regency, making it easier for users to obtain information. The results of ranking the decision support system using the web-based AHP-TOSIS method are shown in Figure 1.

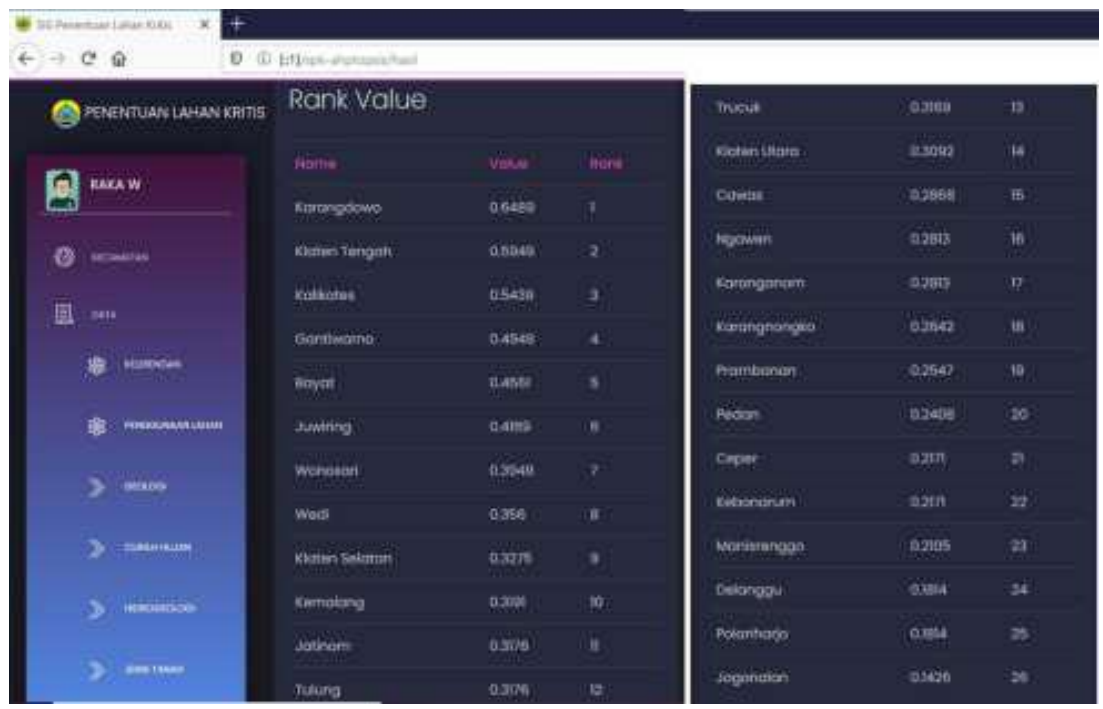

Fig. 1. A Web-based Decision Support System for Critical Land.

\section{Result}

The implementation of Analytic Hierarchy Process and Topsis methods for this Critical Land Decision Support Support System was built using web-based. Alternative data and criteria data can be accessed on the sub-district and data pages. After the data is ready to be processed, the system will dynamically perform the processing using the AHP and TOPSIS methods and the results will be displayed on the system at each step. The use of the combination of AHP and TOPSIS is because the AHP method is less effective when used in cases that have a large number of criteria and alternatives, in this case there are quite a number of alternatives namely 26 alternatives, so combined with the TOPSIS method used to determine the priority level of alternatives to be more effective and efficient in the calculation process. The system that has been made can recommend the Regional Development Planning Agency of Klaten (Bappeda) in determining the priority of critical land in the Klaten Regency. The Supporting System for Critical Land Determination 
Decisions in Klaten District using the Analytic Hierarchy Process and TOPSIS methods built on a web-based result shows that the Karangdowo District area has the highest final yield value of 0.6489 and Jogonalan District with the lowest value of 0.1426 .

\section{Acknowledgment}

The authors are also grateful to the Research and Community Service Institute of Diponegoro University (LPPM-UNDIP) for funding the Research and Development Research (RPP) and Regional Development Planning Agency of Klaten (Bappeda) and Klaten Public Works and Spatial Planning Office (DPUPR).

\section{References}

[1] Y. Shao, Q. Jiang, C. Wang, M. Wang, L. Xiao, and Y. Qi, -Analysis of critical land degradation and development processes and their driving mechanism in the Heihe River Basin,\| Sci. Total Environ., vol. 716, p. 137082, 2020, doi: 10.1016/j.scitotenv.(2020).137082.

[2] D. Patrman, A. Splichalova, D. Rehak, and V. Onderkova, -Factors influencing the performance of critical land transport infrastructure elements,\| Transp. Res. Procedia, vol. 40, pp. 1518-1524, (2019), doi: 10.1016/j.trpro.2019.07.210.

[3] M. Rajasekhar, G. Sudarsana Raju, Y. Sreenivasulu, and R. Siddi Raju, -Delineation of groundwater potential zones in semi-arid region of Jilledubanderu river basin, Anantapur District, Andhra Pradesh, India using fuzzy logic, AHP and integrated fuzzy-AHP approaches, $\|$ HydroResearch, vol. 2, pp. 97-108, (2019), doi: 10.1016/j.hydres.2019.11.006.

[4] A. E. Wolnowska and W. Konicki, -Multi-criterial analysis of oversize cargo transport through the city, using the AHP method,\| Transp. Res. Procedia, vol. 39, no. 2018, pp. 614-623, (2019), doi: 10.1016/j.trpro.2019.06.063.

[5] E. Lima, E. Gorski, E. F. R. Loures, E. A. Portela Santos, and F. Deschamps, -Applying machine learning to AHP multicriteria decision making method to assets prioritization in the context of industrial maintenance 4.0, IFACPapersOnLine, vol. 52, no. 13, pp. 2152-2157, (2019), doi: 10.1016/j.ifacol.2019.11.524.

[6] F. Moussaoui, M. Cherrared, M. A. Kacimi, and R. Belarbi, -A genetic algorithm to optimize consistency ratio in AHP method for energy performance assessment of residential buildings-Application of top-down and bottom-up approaches in Algerian case study,\| Sustain. Cities Soc., vol. 42, pp. 622-636, (2018), doi: 10.1016/j.scs.2017.08.008.

[7] A. Calabrese, R. Costa, N. Levialdi, and T. Menichini, -Integrating sustainability into strategic decision-making: A fuzzy AHP method for the selection of relevant sustainability issues, $\|$ Technol. Forecast. Soc. Change, vol. 139, no. March, pp. 155168, (2019), doi: 10.1016/j.techfore.2018.11.005.

[8] C. Ulloa, J. M. Nuñez, C. Lin, and G. Rey, -AHP-based design method of a lightweight, portable and flexible air-based PV-T module for UAV shelter hangars,॥ Renew. Energy, vol. 123, pp. 767-780, (2018), doi: 10.1016/j.renene.2018.02.099.

[9] M. Khalili, K. Jadidi, M. Karakouzian, and S. Amirkhanian, -Rheological properties of modified crumb rubber asphalt binder and selecting the best modified binder using AHP method,॥ Case Stud. Constr. Mater., vol. 11, p. e00276, (2019), doi: 10.1016/j.cscm.2019.e00276. 
[10] B. Tashayo, A. Honarbakhsh, M. Akbari, and M. Eftekhari, -Land suitability assessment for maize farming using a GIS-AHP method for a semi- arid region, Iran,\| J. Saudi Soc. Agric. Sci., no. xxxx, (2020), doi: 10.1016/j.jssas.2020.03.003.

[11] M. Kim, Y. C. Jang, and S. Lee, -Application of Delphi-AHP methods to select the priorities of WEEE for recycling in a waste management decision-making tool,॥ J.Environ. Manage, $\quad$ vol. $\quad \mathbf{1 2 8}, \quad$ pp. (2013),doi:10.1016/j.jenvman.2013.06.049.

[12] C. Ren, Z. Li, and H. Zhang, - Integrated multi-objective stochastic fuzzy programming and AHP method for agricultural water and land optimization allocation under multiple uncertainties, \| J. Clean. Prod., vol. 210, pp. 12-24, (2019), doi: 10.1016/j.jclepro.2018.10.348.

[13] I. Aşchilean, G. Badea, I. Giurca, G. S. Naghiu, and F. G. Iloaie, -Choosing the Optimal Technology to Rehabilitate the Pipes in Water Distribution Systems Using the AHP Method,\| Energy Procedia, vol. 112, no. October 2016, pp. 19-26, (2017), doi: 10.1016/j.egypro.2017.03.1109.

[14] P. Chen, -Effects of normalization on the entropy-based TOPSIS method,\| Expert Syst. Appl., vol. 136, pp. 33-41, (2019), doi: 10.1016/j.eswa.2019.06.035.

[15] X. Ye, Y. Kang, Z. Yan, B. Chen, and K. Zhong, -Optimization study of return vent height for an impinging jet ventilation system with exhaust/return-split configuration by TOPSIS method,\| Build. Environ., vol. 177, no. April, p. 106858, (2020), doi: 10.1016/j.buildenv.2020.106858.

[16] R. F. de F. Aires and L. Ferreira, -A new approach to avoid rank reversal cases in the TOPSIS method,॥ Comput. Ind. Eng., vol. 132, no. April, pp. 84-97, (2019), doi: 10.1016/j.cie.2019.04.023.

[17] S. Yousefzadeh, K. Yaghmaeian, A. H. Mahvi, S. Nasseri, N. Alavi, and R. Nabizadeh, -Comparative analysis of hydrometallurgical methods for the recovery of $\mathrm{Cu}$ from circuit boards: Optimization using response surface and selection of the best technique by two-step fuzzy AHP-TOPSIS method,\| J. Clean. Prod., vol. 249, p. 119401, (2020), doi: 10.1016/j.jclepro.2019.119401. 